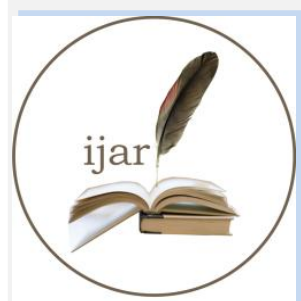

ISSN NO. $2320-5407$
Journal Homepage: - www.journalijar.com INTERNATIONAL JOURNAL OF ADVANCED RESEARCH (IJAR)

Article DOI: $10.21474 / \mathrm{IJAR01} / 1465$

DOI URL: http://dx.doi.org/10.21474/IJAR01/1465
INTERNATIONAL JOURNAL OF ADVANCED RESEARCH (JJAR)

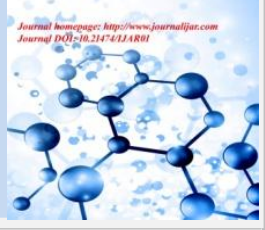

RESEARCH ARTICLE

\title{
FUNCTIONAL TYPOLOGY OF FARMS IN ARID REGIONS CASE OF THE OUED M'YA BOWLS (PROVINCE OF OUARGLA, ALGERIA)
}

Universite Kasdi Merbah Ouargla, 30000 Ouargla, Algerie.

\section{Chaouch Saida.}

\section{Manuscript Info}

Manuscript History

Received: 15 July 2016

Final Accepted: 19 August 2016

Published: September 2016

Key words:-

Oued M' ya, functional typology, farms,

farmers, nomads, neo-farmers,

\section{Abstract}

The region of Oued M'ya is characterized by the coexistence of diverse types of farms, impressive diverse modes of organization and management. To apprehend this diversity, we opted for a functional typology conducted on the basis of the agronomic indicators by means of inquiries in the producing middle. The data processing by the software XL-STAT offering the possibility of realizing an MFA, has allows to highlight the strong contributions and the correlations between variables. The analysis by K-means followed by a clustering by Ascending Hierarchical Classification, has allows the determination of the variables most contributive, appears the irrigation, drainage, location, dominant culture, seniority, the workforce, fertilization, the income and the professional identity of farmer

The study has, identified four clusters corresponding to the types of farms; the old irrigated farms belonging to farmer's oases and those Bours ${ }^{1}$ create by the nomads; form the date tree patrimony of this region. The third type is the improved farms created by public authorities, includes the farms called "Rural Agricultural Sector" created during the colonial period and the agrarian revolution farms attributed to nomads in the objective of their settlement. The fourth type concern the new farms which group the small, medium and large sizes farms created in the framework of new programs of valorization of agricultural land and attributed to the neo-farmers.

Copy Right, IJAR, 2016,. All rights reserved.

\footnotetext{
${ }^{1}$ Farms based on direct water supply from groundwater
} 


\section{Introduction:-}

In the region of Ouargla, called also " Bowl of Oued M'ya " or " Country of Oued M'ya", as somewhere else in Algerian Sahara, the monotony has, for centuries, characterized the agricultural landscape with as shape of only farm "the palm grove" with generally reduced surface dictated by the hostility of the drylands, particularly, the factor "water" and has rather identical structures, functioning and result. The increase of the agricultural surfaces was made with a modest rhythm "during a century, the card of Oasis has not changed, it is only densified" (BRLi, 1999 a). Are the farmer's oases which assured the extension of oases in spaces near and around the Ksours ${ }^{2}$.

The orientation of the country towards an economic policy based on the oil pension made that Ouargla, grafting that central city of the Saharan territory and the oil capital, knew strong socioeconomic mutations; the development of activities other than agricultural and pastoral, in particular in the sector of hydrocarbons, pulled a drainage of the agricultural manpower and this fact an abandonment of the agricultural activity where from the degradation of the productions and the agrarian spaces. "Thanks to the oil extraction, the para-petroleum services, the retail and wholesale, and finally the emergence of the activities of services, the farming sector, can position only later, these first ones in spite of the abundance of the resources in soil and in water. (MADR, 2008)

To face this situation, the Algerian politics has fixed the objective to revitalize the agricultural sector and activity by the earnings of new lands in particular by the promulgation of the law 83-18 of August 13th, 1983 carrying APFA ${ }^{3}$ and of the executive decree 97-483 of December 15th, 1997 concerning the concession of farmlands based on natural resources, particularly water resources now mobilized through drilling techniques and soil suitable for the culturing, hence the introduction of new production systems supported and developed by the neo-farmers.

The passage in farms without or with palm trees and of unusually big sizes of one or several hundred hectares in the objective to introduce and develop strategic cultures in particular cereal, others of the order of around thirty hectares with dominance of subsistence crops and arboriculture and also allotted perimeters in farms of 02 ha for the development of vegetable crops with high added values.

The agricultural landscape in the country of Oued M'ya is, dice then, a mosaic of farms among which the structure, the functioning and the economic result are multiple and diversified. Side to side with the farmer's oases and nomads, the neo-farmers come from four corners of Algeria and all the social strata; entrepreneurs, storekeepers, retired people and even unemployed persons, form the human component whose main objective is the development of agriculture in Ouargla. "They are generally entrepreneurs and storekeepers who, encouraged at first by incentive measures, were the pioneers of a new agriculture which offers promises but with many constraints. (Chaouch, 2006)

\section{Material and methods:-}

\section{Ouargla: region with strong mutations:-}

The region of Ouargla "is in fact the low valley of the Oued M'ya which throws itself with the wadi Mzab and the wadi Nsa into the sebkha Safioun. We can consider that the "country of Ouargla" begins in the South with the ruins of Sédrata and ends in the entrance of the sebkha Safioun $40 \mathrm{~km}$ further north. (Brigol, 1973).This space covering a total area of $19,000 \mathrm{~km}^{2}$ (DPAT, 2015) is limited by the dunes of Sedrata to the South; Sebkhat Safioune in the North; ergs Touil and Arifdji in the East and the east slope of the dorsal of Mzab in the West (BG, 2004).

\footnotetext{
${ }^{2}$ Plural of Ksar which refers to a type of fortified village

${ }^{3}$ Accession to agricultural land ownership
} 


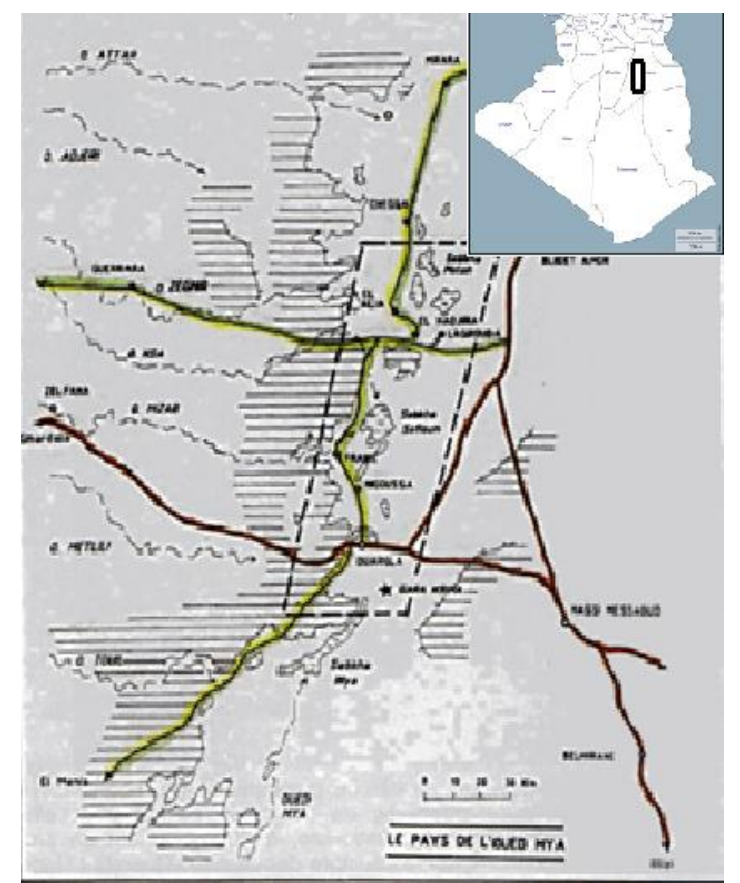

Fig.1:- Situation of the region of Ouargla (Oued Mya). Source of the map of Oued Mya, Côte M, 2016

This space is administratively divided into six municipalities; Ouargla, Rouissat, Ain El Beida, Hassi Ben Abdellah, Sidi Khouiled and N'goussa where live 266.314 inhabitants of which $16 \%$ active in agricultural sector (DPAT, 2015).

This location right in Saharan zone that gives Ouargla its arid climate offers it extraordinary wealth of water reserves underground, form of two gigantic webs, the terminal complex, and, more profoundly, the intercalary continental which exceed the spatial limits of this region to successively cover $350.000 \mathrm{~km}^{2}$ and $600,000 \mathrm{~km}^{2}$ of the Bas-Sahara (Côte, 1998). Soils suitable for cultivation under reserve of fertilization are estimated at 165,000 ha by PDGDRS $^{4}$ study (BRLi 1999 b).

\section{Functional typology: choice based on the specificities of the drylands:-}

The typology of the farms knows several definitions which having the same objective simplified by Palacio "The objective of a typology is to return the multiplicity of the cases which could not be individually treated to a reduced number of types, and to suggest hypotheses of explanation of this diversity. However the approach and the results of the typology vary according to the pursued objectives (Palacio and all, 1995 in Bouammar, 2010).

The studies realized in this domain highlighted several methods of typologies, the most used are the structural typologies and those functional. "As we are going to favor the socioeconomic viewpoint or the technical viewpoint, we can distinguish two groups of typologies: i) the typologies that we shall call structural, that is based essentially on the nature and the modalities of organization and combination of the means of production, ii) functional typologies which become attached more to the analysis of the technical processes of production." (JOUVE, 1986)

Knowing that there is no "standard" model for the construction of typology but this construction is according the objective sought at first and variables of the study "We can characterize the existing typologies by the objectives for which they try to achieve and by the criteria or the variables (...) That they implement " (Brossier and Petit, 1977). It is, thus, the ends, that dictate the choice of the method of typology and the variables to be retained "We can classify the farms of a region of multiple manners according to the reserved criteria and the pursued aims" (Cochet and all, 2011)

${ }^{4}$ Study Design Chief Development for Saharan Regions 
The literature on the typology of farms in the Algerian drylands highlights a blatant deficit of real case studies around this theme. Indeed, the knowledge, information and know how to it make having allows the creation and the development of oases remained "oral" and transmitted by word of mouth " let us not forget that we belong (and study) a society of oral tradition which always confined the paper in the sphere of the sacred and confined it in the circles of powers " (Ababsa, 2007). As a consequence, the classification of the farms in these regions is generally made on the basis of a single criterion such as:

The criterion "sizes": Farms are classified in big, medium and small sized, this criterion is generally adopted for development programs such the case of the PDGDRS study which recommends "to Find the good farms size" by presenting three cases "The big, the small and the medium-sized farms" (BRLi, 1999 b);

The criterion "dates of creation": Farms are divided in former and new, or still, traditional and modern as indicated by Toutain concerning the typology of the oasis "it's date of creation allows to distinguish traditional and modern systems of productions and different modes of development" (Toutain and all, 1989);

The criterion "ecosystem" opposing the oasis's ecosystem against the new one " The Saharan regions of Algeria of which Ouargla is a member of it, knew considerable extensions in term of agricultural areas by the development of new perimeters $(\ldots)$ The current strategy of the agricultural development was applied in the Saharan regions, following the example of the region of Ouargla, turn the back on the classic antique oasis's system." (Korichi, 2007).

However, scales, dates and systems remain vague and diverge according to the viewpoints that we are in an administrative context, of search or in the peasant environment and can so create an overlapping of the ideas and the analysis, in this sense, a particular attention must be given in the choice of typology to be adopted for these regions of which is a part the country of Oued M'ya.

For these regions, "two methods are suggested i) to build the typology of the productive systems by leaving situations and projects of the farmers (Brossier J. and Petit MR.1977). ii) The second method builds the typology on the basis of variables of classification said about structure" (Ababsa, on 2007).

Knowing the multidisciplinary of the agricultural activity, its spreading on several dimensions we gave importance to three scales of analysis evoked by Cochet; the plot or the herd, the production unit or the farm and the region or the country are thus, essential because "It is not only about three different and fitted spatial scales, but also and especially about three interdependent levels of functional organization " (Cochet and all, 2011).

So, the taking into consideration of several criteria linked to the structure and to the functioning of the farms is the best way to know and to understand the decisions of the farmer which determine the functioning of the farms " in a prospect at the same time of understanding and improvement of the farms, it is the whole their functioning, the technical and socioeconomic, that must be taken into account. That militates, naturally, in favor of a multidisciplinary approach to the farm ". (Jouve,1986).

Landais, 1996 specifies "typologies built from a theory of the functioning of the farm considered as a "complex piloted system", theory which is connected with previous numerous works (for example Capillon and Manichon, 1988)". In this sense we inspired by these same works and adopted the following approach:

* Determination of the region object of our study and identification of the agricultural spaces

* Realization of pre- inquiries which are going to succeed in:

- Make a first classification of the categories of the farms;

- Sampling of the farms of the various categories

* Investigate

* Classification and characterization of the farms. 


\section{Data collection: two fundamental stages:-}

Pre- inquiries and sampling: first classification of farms:-

Before beginning our inquiries, we proceeded to pre-inquiries in the various agricultural spaces of the region in the objective to determine the categories of existing farms and to arrest our sample to be submitted to this study. We also based ourselves on the works already realized in this region.

Nine categories of farms were identified and to whom we granted, in first stage, the common naming, collectively adopted by the farmers, the researchers and the local administration. It is about the old irrigated farms, the Bours farms, the farms called $\mathrm{SAR}^{5}$ of the colonial period, the farms of the agrarian revolution, the new small farms of APFA, the new small farms of concession, the medium sized farm, the big one and the business farm. These various categories were already the object of identification (Chaouch, 2006). For our inquiries we retained for survey unit "the farm", we retained 219, distributed by categories as follows:

Table 1:- Distribution of samples by categories of farm.

\begin{tabular}{|l|c|c|c|}
\hline Identification of farms & Counts farm & Number of inquiries & $\%$ \\
\cline { 1 - 3 } Old irrigated farms & \multirow{2}{*}{7229} & 65 & 1,45 \\
\cline { 1 - 3 } Bours farms & 53 & 30 & 28,3 \\
\hline Farms "SAR" of colonial period & 267 & 15 & 11,24 \\
\hline Farms of agrarian revolution & 2147 & 40 & 2,1 \\
\hline Small farms of APFA & 100 & 18 & 83,33 \\
\hline Small farms of concession & 6 & 5 & 18,52 \\
\hline Midium-size farms & 54 & 10 & 100 \\
\hline Big size farms & 1 & 1 & 2 \\
\hline Business farm & & & 2 \\
\hline
\end{tabular}

Source: Chaouch, 2006 on the basis of the data of the $\mathrm{DSA}^{6}$ of Ouargla

For the first two categories of farms, the rate of sampling $(1,45)$ is for information purposes because we have eliminated from our sample the exploitations of very small sizes what is those lower than 0.25 ha for the old irrigated farms and lower than 0.1 ha for the Bours farms what corresponds generally to the farms having less than around thirty productive palm trees, number below which we cannot speak any more about real farms "production unit". These sizes appear (and are) very reduced, this is a specificity of the drylands, at Ouargla, the number of farms of less than 0.5 ha represents $44.82 \%$ of the total and $65,13 \%$ are lower than 1 ha (RGA, 2001). These plots are more and more reduced further to the successive divisions by inheritance.

For the category business farm, the rate of sampling is $100 \%$, we indicate that the region, count at present only one and that we did not eliminate it because it is a very favored model and which the agricultural policy tries to promote in the future.

\section{Investigation in producing environment:-}

The inquiries have been realized on the basis of a questionnaire of the semi-open type. The index card of investigation informs about a series of variables collected by inquiries, directly observable on the field, deducted and/or calculated "based on the knowledge, the methods and the references appropriate to the concerned technical and economic disciplines" (Capillon, 1988). The reserved variables are among 22 represented by 97 modalities grouped in 8 tables.

Table 02:- Tables and variables used in the MFA.

\begin{tabular}{|l|l|l|}
\hline Table & Type of variables & Variables \\
\hline $\mathbf{1}$ & Qualitative & Seniority, location, legal status \\
\hline $\mathbf{2}$ & Qualitative & dominant culture, secondary culture, livestock \\
\hline $\mathbf{3}$ & Quantitative & Age of the farmer, household size \\
\hline $\mathbf{5}$ & Qualitative & Irrigation (drilling), drainage, fertilizer, mechanization \\
\hline
\end{tabular}

\footnotetext{
${ }^{5}$ Rural Agricultural System

${ }^{6}$ Agricultural Services Direction
} 


\begin{tabular}{|l|l|l|}
\hline $\mathbf{6}$ & Quantitative & Total area, cultivated area \\
\hline $\mathbf{7}$ & Quantitative & Palm yield, income/NGMS \\
\hline $\mathbf{8}$ & Qualitative & Professional identification Assets, future projects \\
\hline
\end{tabular}

Certain variables are difficult to determine especially those for whom the farmer, himself, has no exact answer such the case of the income, generally, unknown by the farmer of the fact that the farm is not considered an economically independent production unit and the farmer does not consider a special accounting as his farm " In the almost systematic absence of the economic calculation at the farmers he is not realistic to find a financial accounting nor even a simple accounting subject at the level of the agricultural production units ". (Ababsa, 2007). To face it we estimated the product of farms as follows:

* For the palm tree $=$ Real number of palm trees $\mathbf{x}$ Yield $\mathbf{x}$ Average price to the market

- For the annual cultures $=$ Cultivated surface $\mathbf{x}$ Yield $\mathbf{x}$ Official price or that of the market.

Of this product we subtracted the loads of the farm in the objective to give an approach of the income.

This income is then compared with the NGMS "It is sensible to compare the agricultural income by asset with the salaries which members of the family could hope to gain if they left the farming to work in other branches of industry" (Ferraton and all, 2009). It is going of very low for income lower than the NGMS, at very good income for the farms in more of 150 times NGMS. Indeed, this classification is somewhat arbitrary and other studies can propose other readings.

Data processing by MFA: simultaneous use of the quantitative and qualitative variables It is known that the statistical methods of analysis are the MCA for the qualitative variables and the PCA for the quantitative variables, however variables studied for the typology of farms are both natures and researchers carry out transformations of variables, in order to achieve MCA. The data processing by XLSTAT_MX endowed with the MFA (Multiple Factorial Analysis) method developed by Escofier and Pagès allows analyzing simultaneously quantitative and qualitative variables really collected by inquiries.

The MFA is a statistical analysis in two big stages; the first one is a successive analysis of every table, the MCA for the qualitative variables and the PCA for the quantitative variables. The second stage is a synthesis of the first one by an MFA on the basis of a balanced PCA.

This analysis realized after coding and discretization was followed by k-means analysis and hierarchical Ascendant clustering (AHC) which allows the determination of the number of classes and the synthesis of all the elements of the investigation to characterize each farm type.

\section{Results and the discussion:-}

\section{The eigenvalues:-}

The overall synthesis using the preliminary results in the form of a weighted PCA gives the scree plot in figure 2 below, and we can keep the first two axes which combine $52.54 \%$ of the variability that is considered satisfactory following Kaiser index.

\footnotetext{
${ }^{7}$ National Guaranteed Minimum Salary
} 


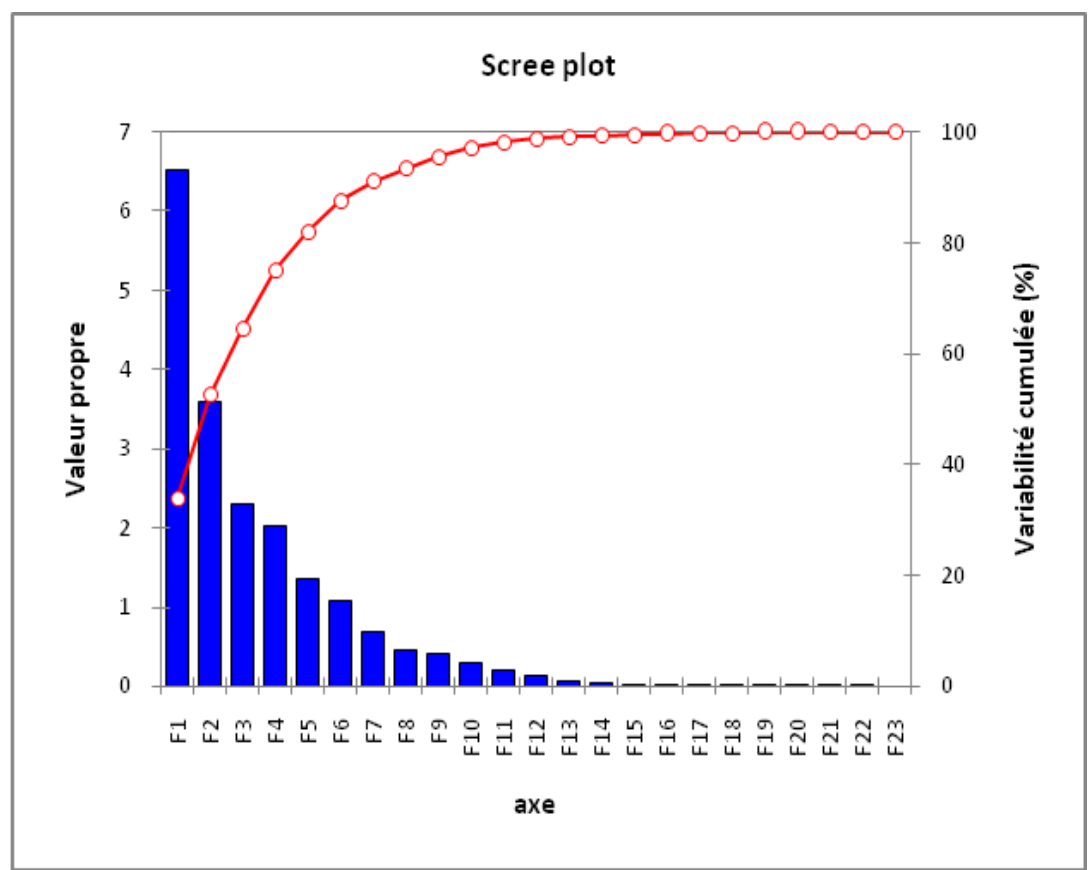

Fig. 02:- Scree plot of the MFA model.

\section{Contribution and correlation of variables:-}

As shown in figure 3 below, they exists three groups of link; the tables of MFA relative to the means of productions, agricultural products, professional identification and projects and the results table are strongly connected to two axes. The tables of the seniority-location-status legal, area and number of farm workers are connected to the first axis while the tables of the age of the farmer and the size of the households seems to have a low contribution for the training of both axes.

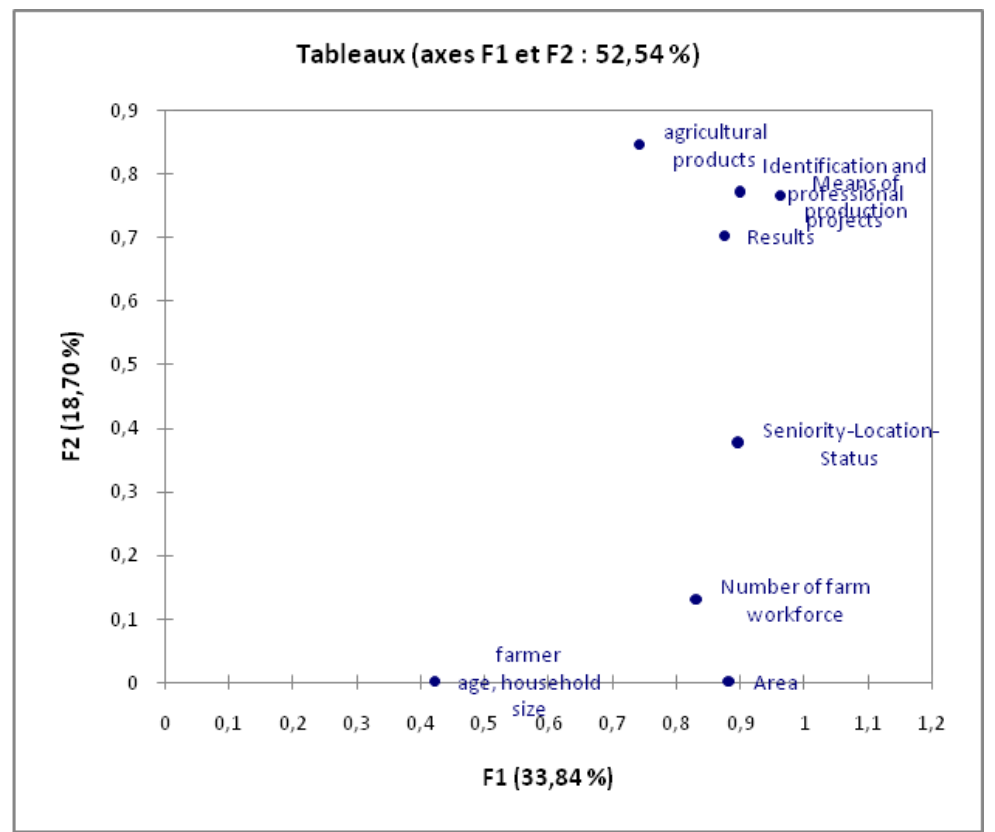

Fig. 3:- contribution of the axes.

\section{RV Coefficients:-}

One of the results mattering for the MFA is the RV coefficients, which is a standardization of the LG coefficients in the form of percentage, the more related tables for the formation of axis. We can see that the table professional identity and projects, has a strong liaison with the tables Production means (0.8841) Productions (0.7607) and 
Seniority-location-status (0.7105) table. The table Number of farm workers is linked to Areas table (0.7635). Also note the link between the productions and means of production tables (0.7499). Other link are remarkable in particular, Productions and Seniority-location-status tables and also the strong link between the result of farms (income) with means of production and that the number of workforce.

Table 3:- RV coefficients of MFA.

\begin{tabular}{|l|c|c|c|c|c|c|c|c|r|}
\hline & 1 & 2 & 3 & 4 & 5 & 6 & 7 & 8 & \multicolumn{1}{c|}{ MFA } \\
\hline 1 & 1,0000 & 0,6873 & 0,2899 & 0,6441 & 0,3956 & 0,5145 & 0,4524 & $\mathbf{0 , 7 1 0 5}$ & 0,7947 \\
\hline 2 & & 1,0000 & 0,2135 & $\mathbf{0 , 7 4 9 9}$ & 0,5081 & 0,4225 & 0,5160 & $\mathbf{0 , 7 6 0 7}$ & 0,8273 \\
\hline 3 & & & 1,0000 & 0,2268 & 0,2292 & 0,2210 & 0,2089 & 0,3091 & 0,4081 \\
\hline 4 & & & & 1,0000 & 0,6559 & 0,5935 & 0,6220 & $\mathbf{0 , 8 8 4 1}$ & 0,8973 \\
\hline 5 & & & & & 1,0000 & $\mathbf{0 , 7 6 3 5}$ & 0,6154 & 0,5781 & 0,7488 \\
\hline 6 & & & & & & 1,0000 & 0,5710 & 0,5429 & 0,7274 \\
\hline 7 & & & & & & & 1,0000 & 0,6714 & 0,7586 \\
\hline 8 & & & & & & & & 1,0000 & 0,9119 \\
\hline MFA & 0,7947 & 0,8273 & 0,4081 & 0,8973 & 0,7488 & 0,7274 & 0,7586 & 0,9119 & 1,0000 \\
\hline
\end{tabular}

1)Seniority-Location-Status 2) agricultural products 3) farmer age, household size 4) Means of production 5) Number of farm workforce 6) Area 7) Results 8) Identification professional and projects

The analysis of the circle of correlation of variables through the graph 5 below allows to notice that the variable of the farm result is strongly bound to the variables of the permanent and seasonal workforce and also to the area and is correlated to the first axis. The yield on palm trees is bound to the presence of the seasonal workforce; the yield is strongly correlated with F2 and the seasonal workforce with F1. The variables, farmer age and household size are strongly bound to the family workforce and negatively correlated to the first axis. It is, indeed, the age of the leader of the exploitation and the household size determines the presence of the family workforce or the appeal to that seasonal and permanent. Total and cultivate area are bound with income, seasonal and permanent workforce. They correlated to the first axis.

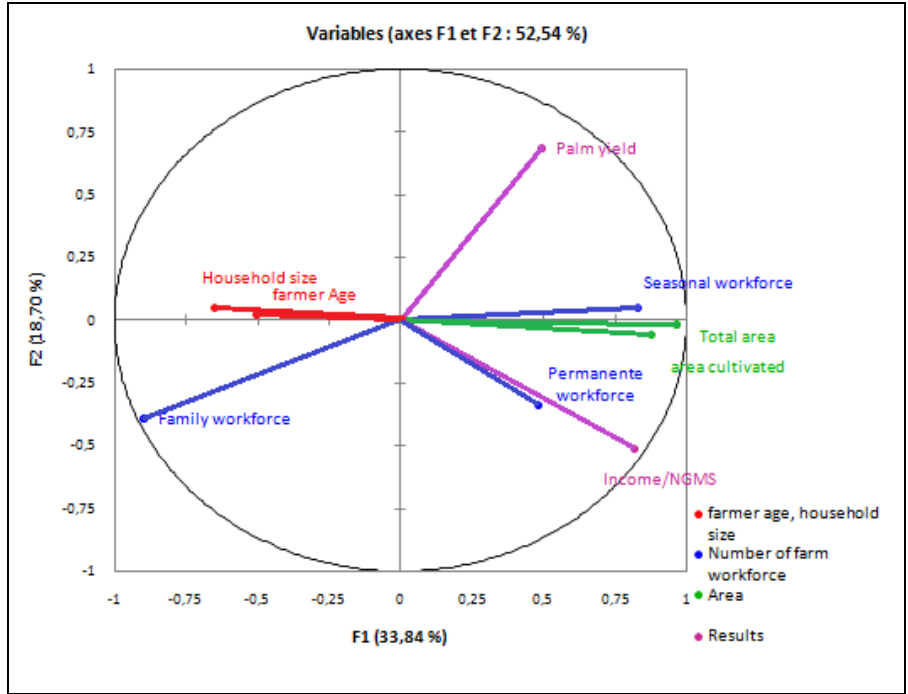

Fig. 4:- Circle of the correlations of variables.

Following the principle which sets that a contribution is judged high when, comparatively at other contributions, it present a value " strongly " high, we executed a k-means analysis and through analysis of variance by Fisher's test it appears that the most contributory variables are irrigation (4707074 x 105) followed by drainage (589695 x 1055). It's the logical of farms in the drylands and endoreic system such as the case of the region of Ouargla.

One other group of variables is also contributory; it is about variables of location (10379), dominant culture (9673), future projects (7358), legal status (4470), mechanization (2727), the cultivated area (1954), the seniority (1629), the professional identity (1611), the income/NGMS (1400), the family workforce (1386) and the fertilization (1034). The variables of relatively means contribution are the second culture (640), which for all the new farms is 
exclusively the date palm, the total area (467), livestock (283), seasonal workforce (234) and permanent workforce (233).

At last, the group of variables with low contribution such as yield palm tree (56) because, except the Bours farms, the yield on the region are average in weak ones, either because of technical conditions, location of the farms or still the age of the palm tree which is or still young or very old. The age and the level of farmer and household size, the present the most low values of F (29 and 18) respectively.

\section{Clustering and characterization of the farms:-}

The clustering by hierarchical ascending classification (HAC) based on the method of "Ward Linkage" which favorites the fast training of homogeneous groups in the objective to determine the number of cluster presented by the dendogramme or hierarchical tree with an automatic cup (figure 5, point A) at three big types of farms, however we have chosen a cut at four types of farms (figure 5, point B) which distingue between the Bours type and the type of improved farms and given the classification followed:

* Cluster 1: The old irrigated farms.

* Cluster 2: the Bours farms;

* Cluster 3: the $\mathrm{EAI}^{8}-\mathrm{EAC}^{9}$ called SAR farms and those of the agrarian revolution;

* Cluster 4: all new farms namely the small farms of the APFA and Concession program, medium-sizes farms, big sizes farms and the business farm.

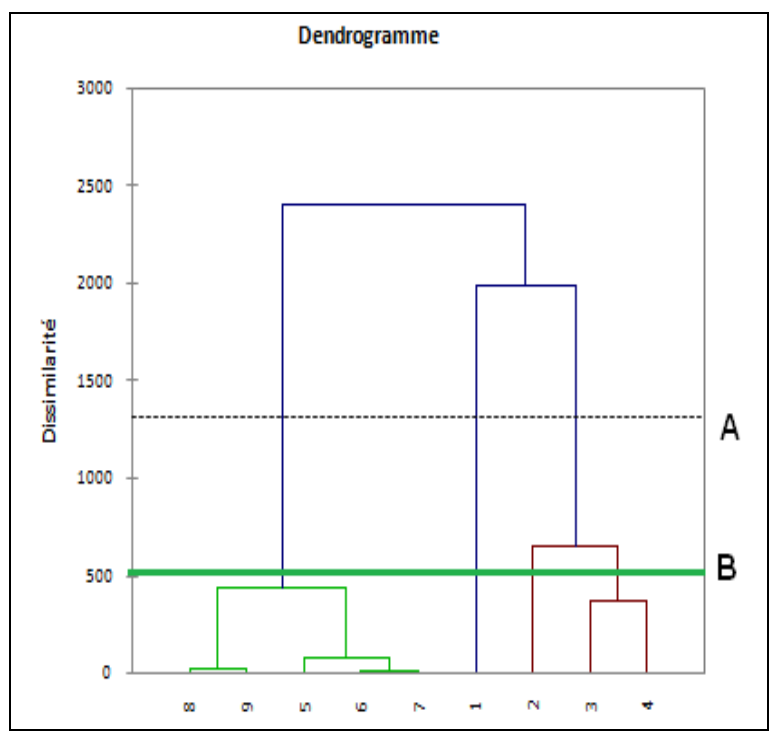

Fig. 5:- Hierarchical tree or dendrogramme of the farms of the region of Ouargla.

The decomposition of the variance for the optimal classification (table 4) presents a very important percentage of variance inter-class of 95,52\% and an intra-class variance to only 4,48\% what leads us to opt for this classification in type of farms "Good typology should reveal both a maximum heterogeneity between each type and maximum homogeneity within each type" (Kobrich and al., in Loubier S., 2003).

Table 4:- decomposition of the variance for the optimal classification.

\begin{tabular}{|l|c|}
\hline & Percentage \\
\hline Intra-class & $4,48 \%$ \\
\hline Inter-class & $95,52 \%$ \\
\hline Total & $100,00 \%$ \\
\hline
\end{tabular}

These results of the functional typology are approximate the structural typology realized on the same region and using even inquiries but limited, however, to the structural indicators and giving five types of farms with distinction

\footnotetext{
8 Agricultural Individual Farm

${ }^{9}$ Agricultural Collective Farm
} 
between the new farms ranged the small farms on the one hand and the medium and large one on the other hand (chaouch, 2016). This leads us to conclude that the farms Ouargla have five types of structure and four type of functioning. In effect the new farms (cluster 4) have different structures between small farms compared to medium and large one but have the same functioning logic.

\section{Characterization of the farms types :-}

On the basis of the most contributory variables, we presented main characteristics of each one of the five types of the farms.

The old irrigated farms where farmer's oasis have not any clearly stated objectives:-

Old farms located at the heart of the bowl of Oued M' ya, of much reduced sizes, an average of 0.7 ha, irrigated from collective drillings with however a defective drainage. The palm date production is the unique activity for the old owners and is secondary for the youngest. They base themselves on a hand of family work assisted by seasonal workers during the periods of pollination and harvest.

The owners, farmers oases of filiations, the farms their returns by inheritance and which stays in the joint possession with a morality attachment which constitutes the main assets however the inextensibility of the farms and the weakness of income constitute a major constraint which with the advanced age of the leaders of the farms and the flight of the hand of family work make that these farmers have not any clearly stated objectives.

\section{The Bours farms and the nomads in conquest of the space:-}

This type of farms is based on the irrigated from the groundwater and from the natural drainage. They are microfundio in the form of alveoli planted in around thirty at fifty palm trees. From private custom status legal, they are planted along the nomadic tracks by the nomads themselves for centuries. "The populations sowed with way more in the least voluntary of date stones, obtained plantations where they practiced cultures of pickings (Côte, 2006).

The farming is the main activity. The availability of water of the groundwater, even if by place knows a strong drawdown, constitutes a major assets of these farms and also fact that the objectives of farmers are moving towards extending the cultivated farmland integrating a hand of family work with the cooperation of the young people and women. However, the constraint is "the forgetting" of these patrimony by the public authorities.

\section{The improved exploitations and the saving of the existing:-}

They are palm groves relatively more recent (create in 1958 and in 1971) to be attributed to nomads become sedentary, very near to the urban area. The size of the farms is homogeneous to 1 at 1,5 ha, irrigated by collective drillings and has system of drainage in continual degradation. It is based on a seasonal workforce, next to the family increasingly rare.

The main assets of these farms it's that they have were obtained in "keys in hand" in the form of EAI or EAC what establishes paradoxically the major constraint because the public domain status legal inhibits all initiatives owners and limit the objectives in the protection of the current without dashing into projects without any guaranteed.

\section{The new farms under constraint of the water:-}

They are a recent farms created by state in the framework of the law 83/18 carrying APFA and decree 97-483 related to concession localized taken away from urban areas and even "isolated". We distingue a small farms of 2 ha, and the medium-size farms ( $30 \mathrm{ha}$ ) based, at the ensemble, on the production of vegetable crops with high added value and also a big-size farms of 64 to 200 ha and can attain 1670 ha created in the objective to produce a strategic cultures in particular cereal irrigated by pivots

Except the business farm of ERIAD ${ }^{10}$ of status EPIC ${ }^{11}$, these new farms are attributed to neo-farmers whose functionary, entrepreneurs, storekeepers and unemployment "On the regulatory side, the allocation of land for development in the context of the concession is intended exclusively for the unemployed (a certificate of inactivity is essential in the folder); this measure falls within the framework of the government's program to fight against

\footnotetext{
${ }^{10}$ Regional business of Food Industries and Derivatives

${ }^{11}$ Public Company to Industrial and Commercial character
} 
unemployment)"(Dadamoussa, 2007), encouraged by the incentive measures that the state has provided for the creation and the functioning of farmers.

The irrigation is provided from collective drilling for the small farms and by one or several individual drilling for the medium and big size farms. However water deficit and charges of electricity are the principle constraints for this farms which, too, are strong consumer of fertilizer and phytosanitary products require a big cost oblige the neofarmers to maintain, in parallel, other activities in the business sector, commerce and even in the informal setting limiting the agricultural activity to winter time and manpower to than seasonal.

At fact, this new programs of agricultural development initiated by the public authority in the objective to diversification of products and agricultural system has marked a strong adhesion especially for the big-size farms "the installation of cereal's farms respond much more to the will of the public authorities to augmented the national production cereal that the initiative of investment private or entrepreneur "pioneers". however the current strategy of the rural development putting first and foremost the palm date production for the Saharan regions made that objectives of neo-farmers is, henceforth, the conversion of date palms farms by the mass plantation of the palm tree so having the double advantage to take advantage of the State support and invest for a production very known, developed and marketed by the Saharan.

\section{Conclusion:-}

This study is based on a functional typology by the use of the MFA which allowed to makes the synthesis of the data collected by the inquiries that they are quantitative or qualitative. This method demonstrate that we can't based at only one criterion to distinguished a different type of farms and in the drylands, a several variables must be integrated to form and refine the types of farms in the region.

This reveals that the most contributory variables and dictate the functioning of farms are the irrigation, the drainage, followed by the variables location, dominant culture, future projects, status legal, seniority of the farms, income/SNMG and the fertilization. Another variables are, also, a relatively strong contributory such as a second culture, the professional identity of the owner that are farmers oases, nomads or neo-farmers and also the family, seasonal or permanent workforce. However, the age of farmer and the household size are a very low contribution for the building of this typology.

The analysis propose a cut at three types of farms but the logic of farms functioning impose to opted for four farms types in the region of Oued M'ya clearly distinguished by diverse combination of variables study. We have identified the old irrigated farms belonging to oasis farmer's, the Bours farms create by the nomads, the farms called improved, including the EAI and EAC of the last SAR and those of the agrarian revolution attributed to nomads with the aim of their settlement, and at last, the type of new farms regroup the small, medium and the big size farms attributed to a neo-farmers whose simple functionary, retired, unemployed and also a potential beneficiaries which entrepreneurs and traders. Indeed, outside the total area, which weakly cultivated the strongly contributory variables indicate that all new farms which small, middle and large sizes have the same logic of existence and functioning.

We can conclude that the farms in the arid region Ouargla are, more than elsewhere, sensitive to small variations and require the methods of typology and analysis based on data from both, of the overall visions and retail in order to highlight the types of characteristics farms in this arid region.

\section{Bibliography:-}

1. Ababsa, Smati. (2007): Introduction au cours de socio-économie du développement durable des régions sahariennes en Algérie. I.N.R.A., Alger, $2^{\text {nd }}$ Ed. ISSN : 1112-7929 : 207.

2. BG. (2004) : Etude d'assainissement des eaux résiduaires, pluviales et d'irrigation. Mesures complémentaires de lutte contre la remontée de la nappe phréatique : Rapport of mission II A .Essai de pompage. Bonard \&t Gardel, Lausanne.

3. Bouammar B. (2010) : Le développement agricole dans les régions sahariennes : étude de cas de la région de Ouargla et de la région de Biskra : Doctoral thesis, Ouargla university : Algérie, $293 \mathrm{p}$

4. BRLi (1999 a): Etude du Plan Directeur Général de Développement des Régions Sahariennes, Lot I. Indicateurs de développement : 94. 
5. BRLi (1999 b) : Etude du Plan Directeur Général de Développement des Régions Sahariennes, Lot 2, Phase II : Recherche d'options de développement agricole : 138p.

6. Brigol M.R. (1973) : Variations et organisation d'un espace rural au milieu désertique : Le pays de Ouargla (Sahara Algérienne) : Doctoral thesis, Sorbonne University, Paris, 273p.

7. Brossier J. et Petit M. (1977) : Pour une typologie des exploitations agricoles fondée sur les projets et les situations des agriculteurs : in Économie rurale. 22. pp. 31-40.

8. (http://www.persee.fr/web/revues/home/prescript/article/ecoru_00130559_1977_num_122_1_2520).

9. Capillon A., Legendre J., Simier J.P., Vedep G. (1988): Typologies et suivis technico-économiques d'exploitations: quels apports pour l'amélioration des systèmes fourragers ? Exposé présenté aux Journées A.F.P.F. pp 273-296.

10. Capillon A. et Manichon H. (1988) : Guide d'étude de l'exploitation agricole à l'usage des agronomes. Relance agronomique : ADEPRiNA / APCA : Paris, 48 p.

11. Chaouch S. (2006) : Développement agricole durable au Sahara nouvelles technologiques et mutations socioéconomiques le cas de la région d'Ouargla. Doctoral thesis, Aix Provence-Marseille university: 390p.

12. Chaouch S. (2016): Typology of farms in the region of Ouargla "bowl of Oued Mya" by using the MCA. In $\begin{array}{llll}\text { ISROSET-IJSRMS. } & 2 & \text { (6): } & \text { ISSN }\end{array}$ http://www.isroset.org/journal/IJSRMS/current_issue.php).

13. Cochet H., (2011) : Origine et actualités du «système agraire »: Retour sur un concept : in Revue Tiers Monde 2011/3 : $207:$ 97-114 http://www.cairn.info/revue-tiers-monde-2011-3-page-97.htm

14. Côte M, 1998, « Des oasis malade de trop d'eau »in Sécheresse 9 (2) : pp 123-130

15. Côte M. (2006), Si le Souf m'était conté. Comment se fait et se défait un paysage. Ed. Média-Plus ISBN : $9961-$ 922-42-5:135p.

16. Côte M. (2016) : Si l'Oued Mya m'était conté : Petite géographie de Ouargla : in «Les cahiers de Ouargla » ${ }^{\circ}$ 06, Association du Ksar pour la Culture et l'Islah de Ouargla 50p.

17. Dadamoussa M. L. (2007) : Les effets induits des différents programmes de développement agricole sur la préservation de l'écosystème saharien. Cas de la région de Ouargla : Magister Thesis : 145p.

18. DPAT. (2015) : Statistiques agricoles de la wilaya de Ouargla, 184p

19. Ferraton N. et all (2009) : Comprendre l'agriculture familiale. Diagnostic des systèmes de production. Ed. Quae, CTA, Presses agronomiques of Gembloux. ISBN 978-2-7592-0340-6 : 135p.

20. Jouve P. (1986) : Quelques principes de construction de typologie d'exploitations agricoles suivant différentes situations agraires : Communication in colloque « Diversification des modèles de développement rural » MRT Paris in «Les Cahiers de la Recherche Développement n 11 , ».

21. Korich B. (2007) : La vulgarisation agricole et son impact sur la préservation de l'écosystème oasien. Cas de la région de Ouargla : magister thesis : $111 \mathrm{p}$.

22. Landais E. (1996) : Typologies d'exploitations agricoles. Nouvelles questions, nouvelles méthodes, in Économie rurale $236:$ pp. $3-15$.

23. ( http://www.persee.fr/web/revues/home/prescript/article/ecoru_00130559_1996_num_236_1_4819).

24. Loubier S. (2003) : Modélisation du comportement des agriculteurs : in Revue de littérature. Rapport Final BRGM/RP-53172-FR : 30p.

25. MADR, (2003) : Recensement général de l'agriculture-2001: Rapport général des résultats définitifs : 125p.

26. MADR. (2008) : La main d'œuvre au niveau des exploitations agricoles 2006/07 : 50p.

27. Toutain G. Dollé V. Ferry M. (1989) : Situation des systèmes oasiens en régions chaudes. Communication in seminar "Les systèmes agricoles oasiens" Tozeur (Tunisie) : In Les Cahiers de la Recherche Développement 22. 